\title{
IMPACT OF GLOMUS FASCICULATUM AND FLUORESCENT PSEUDOMONAS ON GROWTH PERFORMANCE OF VIGNA RADIATA (L.) WILCZEK CHALLENGED WITH PHYTOPATHOGENS
}

\author{
Muthuramalingam Jothi Basu*, Karuppagnaniar Santhaguru
}

Lecturer in Bothany, Directorate of Distance Education, Alagappa University

Alagappapuram, Karaikudi-630 003, Tamilandu, India

Received: January 25, 2009

Accepted: May 15, 2009

\begin{abstract}
Fusarium oxysporum and Rhizoctonia solani are the major soil-borne pathogens causing growth and yield depression. The present study focused on the ability of fluorescent Pseudomonas and Glomus fasciculatum on growth performance of Vigna radiata in pathogen-infested soil. The percent colonization by G. fasciculatum indicated an increase of the presence of fluorescent Pseudomonas and a decrease of the presence of Fusarium oxysporum or Rhizoctonia solani. However, the reduction of colonization induced pathogen in percent was alleviated by fluorescent Pseudomonas. Inoculation with either fluorescent Pseudomonas or G. fasciculatum or both induced a significant increase in root and shoot length, plant vigour index, dry weight and total $\mathrm{N}$ and $\mathrm{P}$ content in $V$. radiata as compared to uninoculated control. The impact of inoculation was much pronounced in dual inoculated plants in comparison with those inoculated with either G. fasciculatum or fluorescent Pseudomonas. In contrast, treatment of plants with either F. oxysporum or R. solani decreased the root and shoot length, plant vigour index, dry weight and total $\mathrm{N}$ and $\mathrm{P}$ content in the test legume. However, in the presence of fluorescent Pseudomonas and G. fasciculatum, the adverse effect on the pathogens on growth of $V$. radiata was alleviated.
\end{abstract}

Key words: Glomus fasciculatum, fluorescent Pseudomonas, growth, Vigna radiata, phytopathogens

\section{INTRODUCTION}

The rhizosphere bacteria beneficial to plants are often referred to as Plant Growth Promoting Rhizobacteria or PGPR (Kloepper et al. 1989). The PGPR can positively influence plant growth by syntheizing plant growth promoting substances or by facilitating the uptake of certain nutrients from the environment. Among the PGPR, fluorescent pseudomonads received considerable interest because of their ability to suppress soil-borne plant pathogens, in addition to promoting plant growth.

Arbuscular mycorrhizal fungi (AM fungi) are of special interest in tropics because of their association with a large number of agricultural crop plants. The benefits of AM fungi include better uptake of nutrients, especially $\mathrm{P}$, suppression of soil-borne plant pathogens, tolerance to water stress, production of plant growth hormones and mobilization of minor elements. The PGPR are synergistic with mycorrhizae in plant growth stimulation and may stimulate root colonization by mycorrhizal fungi (Bagyaraj and Menge 1978; Meyer and Linderman 1986; Chanway and Holl 1991). There are very few dual inoculation data of AM fungi and PGPR especially fluorescent Pseudomonas of crop plants. This study is aimed to recongnize the impact of dual inoculation involving fluorescent Pseudomons strain VuPf1 and Glomus fasciculatum on growth performance of Vigna radiata challenged with phytopathogens.

\section{MATERIALS AND METHODS}

Fluorescent Pseudomonas, G. fasciculatum, F. oxysporum and $R$. solani were obtained from the Department of Botany, Thiagarajar College, Madurai. Seeds of $V$. radiata variety VA02 were obtained from Tamil Nadu Agricultural Department, Madurai. Seeds of $V$. radiata were surface sterilized with $0.1 \% \mathrm{HgCl}_{2}$ for 2 min and bacterized with fluorescent Pseudomonas strain VuPf1. F. oxysporum and $R$. solani were cultivated in natural medium (sorghum seeds soaked in sucrose solution and autoclaved) and fungal cultures were incorporated into the sterile soilsand mixture (2:1 ratio) in earthen pots. The following treatment schedule was followed:

$\mathrm{T}_{1}$ Uninoculated control

$\mathrm{T}_{2}$ Fluorescent Pseudomonas inoculation

$\mathrm{T}_{3}$ G. fasciculatum inoculation

$\mathrm{T}_{4}$ Fluorescent Pseudomonas + G. fasciculatum inoculation

$\mathrm{T}_{5}$ F. oxysporum inoculation

$\mathrm{T}_{6}$ R. solani inoculation

$\mathrm{T}_{7}$ Fluorescent Pseudomonas + F. oxysporum inoculation

$\mathrm{T}_{8}$ Fluorescent Pseudomonas $+R$. solani inoculation

$\mathrm{T}_{9}$ G. fasciculatum + F. oxysporum inoculation 
$\mathrm{T}_{10}$ G. fasciculatum + R. solani inoculation

$\mathrm{T}_{11}$ Fluorescent Pseudomonas + G. fasciculatum + F. oxysporum inoculation

$\mathrm{T}_{12}$ Fluorescent Pseudomonas + G. fasciculatum + R. solani inoculation

Sterile tap water was used to water the plants. Plants were harvested 35 days after inoculation.

Plant materials were cut into bits and dried in an oven at $90^{\circ} \mathrm{C}$ for 3 days and dry weight was determined. The plant vigour index was determined by multiplying percent germination and root + shoot length. Fine roots were stained using trypan blue (Phillps and Hayman 1970) and the percent root colonization was calculated by grid-line intersect method (Giovannetti and Mosse 1980). Total nitrogen content was estimated according to the modified micro-Kjeldahl method (Umbriet et al. 1972). Acid-soluble total phosphorus was estimated by the method of FiskiSubba Rao as modified by Bartlett (1959). The data were subjected to statistical analysis using IRRISTAT package for one way analysis of variance and Duncan's Multiple Range Test (DMRT).

\section{RESULTS AND DISCUSSION}

Dual inoculation with fluorescent Pseudomonas and G. fasciculatum induced an increase in root and shoot length of $V$. radiata (Table 1 ). In contrast, the root and shoot length was significantly reduced following pathogen treatment. The pathogen-induced reduction in root and shoot length was compensated by mycorrhizal and fluorescent Pseudomonas inoculation. The data presented in figure 1 . showed an increase in vigour index of $V$. radiata upon inoculation with either fluorescent Pseudomonas or G. fasciculatum or both. The index was drastically reduced by pathogen treatment. However, the pathogen-induced effect on the index was nullified upon fluorescent Pseudomonas + G. fasciculatum inoculation. Increased seed germination, root and shoot growth, greater seedling vigour index caused by $P$. fluorescens was demonstrated in several crops (Ramamoorthy et al. 2001; Khalid et al. 2004; Egamberdieva 2008). The increased plant growth reported here would possibly be the result of hormonal action since fluorescent Pseudomonas is able to produce substantial quantity of IAA and GA in culture medium (date not shown).

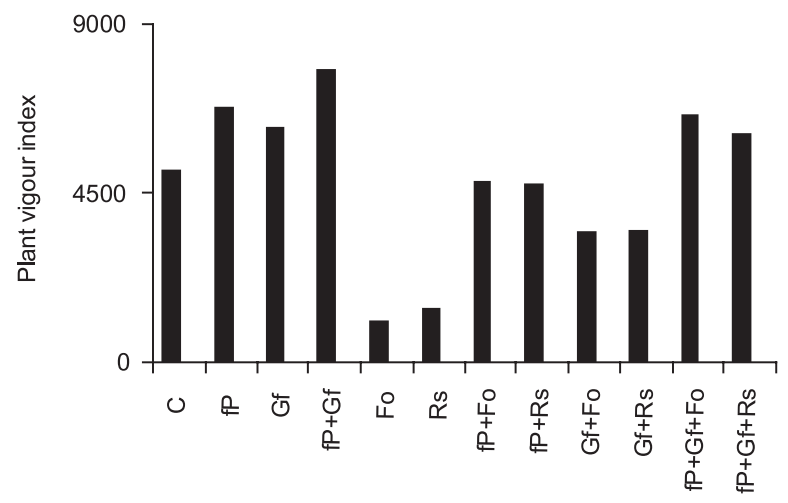

Treatments

Fig. 1. Inoculation of fluorescent Pseudomonas and G. fasciculatum on vigour index of $V$. radiata grown in pathogen infested soil at 35 DAI

The results presented in table 2 showed that dual inoculation with fluorescent Pseudomonas and G. fasciculatum enhanced the mycorrhizal colonization. Earlier studies have also shown a positive influence of dual inoculation involving AM fungi and rhizobacteria on mycorrhizal colonization (Meyer and Linderman 1986; Duponnois and Plenchette 2003; Gamalero 2004; Akhtar and Siddique 2008). Reduction in percent colonization of G. fasciculatum in the presence of F. oxysporum or R. solani and alleviation of pathogen effect by colonization with mycorrhizal fungi and fluorescent Pseudomonas could be due to the produc-

Table 1. Inoculation of fluorescent Pseudomonas and G. fasciculatum on root and shoot length of $V$. radiata grown in pathogen infested soil at $35 \mathrm{DAI}$

\begin{tabular}{|l|c|c|}
\hline \multicolumn{1}{|c|}{ Treatment } & $\begin{array}{c}\text { Root length } \\
{[\mathrm{cm} / \mathrm{plant}]}\end{array}$ & $\begin{array}{c}\text { Shoot length } \\
{[\mathrm{cm} / \text { plant] }}\end{array}$ \\
\hline Uninoculated control & $30.66 \mathrm{~d} \pm 2.08$ & $20.00 \mathrm{~b} \pm 4.58$ \\
\hline Fluorescent Pseudomonas & $32.66 \mathrm{de} \pm 1.71$ & $35.00 \mathrm{~g} \pm 2.00$ \\
\hline Glomus fasciculatum & $31.33 \mathrm{~d} \pm 1.15$ & $30.66 \mathrm{de} \pm 1.73$ \\
\hline Fluorescent Pseudomonas + G. fasciculatum & $36.66 \mathrm{e} \pm 2.93$ & $40.83 \mathrm{~g} \pm 2.75$ \\
\hline Fusarium oxysporum & $13.83 \mathrm{a} \pm 1.75$ & $7.5 \mathrm{a} \pm 1.32$ \\
\hline Rhizoctonia solani & $17.33 \mathrm{ab} \pm 0.57$ & $8.0 \mathrm{a} \pm 1.46$ \\
\hline Fluorescent Pseudomonas + F. oxysporum & $24.00 \mathrm{c} \pm 0.58$ & $23.66 \mathrm{c} \pm 1.08$ \\
\hline Fluorescent Pseudomonas + R. solani & $24.16 \mathrm{c} \pm 2.75$ & $23.00 \mathrm{c} \pm 3.46$ \\
\hline G. fasciculatum + F. oxysporum & $18.83 \mathrm{~b} \pm 0.78$ & $28.66 \mathrm{~d} \mathrm{e} \pm 2.08$ \\
\hline G. fasciculatum + R. solani & $18.50 \mathrm{~b} \pm 2.18$ & $27.16 \mathrm{~d} \pm 0.43$ \\
\hline Fluorescent Pseudomonas + G. fasciculatum + F. oxysporum & $31.00 \mathrm{~d} \pm 0.57$ & $34.33 \mathrm{f} \pm 0.57$ \\
\hline Fluorescent Pseudomonas + G. Fasciculatum + R. Solani & $29.00 \mathrm{~d} \pm 1.26$ & $31.50 \mathrm{ef} \pm 0.59$ \\
\hline F value & 34.35 & 88.53 \\
\hline
\end{tabular}

\pm Standard deviation

$p<0.05$ values marked with different letters in the same column indicates significant differences 
Table 2. Influence of inoculation of fluorescent Pseudomonas and G. fasciculatum on mycorrhizal infection in roots of $V$. radiata grown in pathogen infested soil at $35 \mathrm{DAI}$

\begin{tabular}{|l|c|c|}
\hline \multicolumn{1}{|c|}{ Treatment } & Hyphal infection & Vesicular infection \\
\hline Glomus fasciculatum & $49.39 \mathrm{~cd} \pm 2.40$ & $28.69 \mathrm{~b} \pm 3.02$ \\
\hline Fluorescent Pseudomonas + G. fasciculatum & $51.19 \mathrm{~d} \pm 2.06$ & $35.13 \mathrm{c} \pm 1.59$ \\
\hline G. fasciculatum + F. oxysporum & $38.66 \mathrm{~b} \pm 2.30$ & $21.33 \mathrm{a} \pm 2.30$ \\
\hline G. fasciculatum + R. solani & $35.23 \mathrm{a} \pm 1.65$ & $18.28 \mathrm{a} \pm 1.67$ \\
\hline Fluorescent Pseudomonas + G. fasciculatum + F. oxysporum & $44.00 \mathrm{~b} \pm 4.00$ & $26.66 \mathrm{~b} \pm 2.30$ \\
\hline Fluorescent Pseudomonas + G. fasciculatum + R. Solani & $45.00 \mathrm{bc} \pm 1.00$ & $26.64 \mathrm{~b} \pm 1.51$ \\
\hline F value & 13.90 & 22.58 \\
\hline
\end{tabular}

\pm Standard deviation

$\mathrm{p}<0.05$ values marked with different letters in the same column indicates significant differences

tion of antifungal compound. However, it is worthwhile to note that antifungal compounds produced by Pseudomonas spp did not interfere with AM formation or functioning (Barea et al. 1998; Vazquez et al. 2000).

The PGPR are synergistic with mycorrhizae in stimulating plant growth (Meyer and Linderman 1986; Chanway and Holl 1991). As shown in table 3 and 4 dual inoculation with fluorescent Pseudomonas and G. fasciculatum enhanced the plant biomass, $\mathrm{N}$ and $\mathrm{P}$ accumulation as compared to single inoculation with either fluorescent Pseudomonas or G. fasciculatum. In an earlier report, Akhtar and Siddique (2008) observed a synergistic interaction between $G$. intraradices and $P$. alcaligens which resulted in increased biomass, total nitrogen and total phosphorus accumulation. The ill-effects of F. oxysporum and R. so- lani on plant biomass, and $\mathrm{N}$ and $\mathrm{P}$ accumulation were significantly reduced upon fluorescent Pseudomonas + G. fascicultum inoculation.

It is clearly noted that fluorescent Pseudomonas synergistic with mycorrhiza enhances the plant growth and biomass by producing plant growth promoting substances on one hand and antibiotics on the other hand, but without affecting the formation and functioning of mycorrhizal fungi. The present study revealed that an efficient biocontrol strain of fluorescent Pseudomonas strain VuPf1 in combination with G. fasciculatum alleviated the adverse effects of the pathogens in $V$. radiata. Thus fluorescent Pseudomonas and G. fasciculatum can be exploited for enhancing the productivity of $V$. radiata even if the soils are infested with phytopathogens.

Table 3. Influence of inoculation of fluorescent Pseudomonas and G. fasciculatum on dry weight accumulation in $V$. radiata grown in pathogen infested soil at $35 \mathrm{DAI}$

\begin{tabular}{|l|c|c|}
\hline \multicolumn{1}{|c|}{ Treatment } & $\begin{array}{c}\text { Root Dry wt. } \\
\text { [g/plant] }\end{array}$ & $\begin{array}{c}\text { Shoot Dry wt. } \\
{[\mathrm{g} / \mathrm{plant}]}\end{array}$ \\
\hline Uninoculated control & $0.19 \mathrm{bcd} \pm 0.04$ & $0.47 \mathrm{bcd} \pm 0.06$ \\
\hline Fluorescent Pseudomonas & $0.31 \mathrm{ef} \pm 0.02$ & $0.99 \mathrm{f} \pm 0.19$ \\
\hline Glomus fasciculatum & $0.29 \mathrm{e} \pm 0.05$ & $1.45 \mathrm{~g} \pm 0.14$ \\
\hline Fluorescent Pseudomonas + G. fasciculatum & $0.32 \mathrm{ef} \pm 0.09$ & $0.11 \mathrm{a} \pm 0.03$ \\
\hline Fusarium oxysporum & $0.02 \mathrm{a} \pm 0.004$ & $0.24 \mathrm{ab} \pm 0.08$ \\
\hline Rhizoctonia solani & $0.05 \mathrm{ab} \pm 0.03$ & $0.737 \mathrm{def} \pm 0.05$ \\
\hline Fluorescent Pseudomonas + F. oxysporum & $0.22 \mathrm{~d} \pm 0.05$ & $0.57 \mathrm{cde} \pm 0.04$ \\
\hline Fluorescent Pseudomonas + R. solani & $0.21 \mathrm{~cd} \pm 0.06$ & $0.31 \mathrm{abc} \pm 0.02$ \\
\hline G. fasciculatum + F. oxysporum & $0.09 \mathrm{abc} \pm 0.01$ & $0.30 \mathrm{abc} \pm 0.07$ \\
\hline G. fasciculatum + R. solani & $0.10 \mathrm{abc} \pm 0.01$ & $0.75 \mathrm{def} \pm 0.10$ \\
\hline Fluorescent Pseudomonas + G. fasciculatum + F. oxysporum & $0.29 \mathrm{~d} \pm 0.05$ & $0.81 \mathrm{def} \pm 0.09$ \\
\hline Fluorescent Pseudomonas + G. fasciculatum + R. Solani & $0.24 \mathrm{~d} \pm 0.08$ & 12.61 \\
\hline F value & 3.98 & \\
\hline
\end{tabular}

\pm Standard deviation. $\mathrm{p}<0.05$ values marked with different letters in the same column indicates significant differences 
Table 4. Influence of inoculation of fluorescent Pseudomonas and G. fasciculatum on total nitrogen content and total phosphorus content of $V$. radiata grown in pathogen infested soil at $35 \mathrm{DAI}$

\begin{tabular}{|c|c|c|c|c|}
\hline \multirow[t]{2}{*}{ Treatment } & \multicolumn{2}{|c|}{$\begin{array}{c}\text { Total nitrogen content } \\
{[\mathrm{mg} \mathrm{N} / \text { plant }]}\end{array}$} & \multicolumn{2}{|c|}{$\begin{array}{c}\text { Total phosphorus content } \\
\text { [mg P/plant] }\end{array}$} \\
\hline & root & shoot & root & shoot \\
\hline Uninoculated control & $4.56 \mathrm{ab} \pm 0.93$ & $17.50 \mathrm{bcd} \pm 0.12$ & $0.39 \mathrm{abc} \pm 0.08$ & $0.77 \mathrm{abc} \pm 0.08$ \\
\hline Fluorescent Pseudomonas & $16.61 \mathrm{~d} \pm 0.7$ & $52.52 \mathrm{fg} \pm 3.48$ & 0.92 de \pm 0.08 & $2.884 \mathrm{f} \pm 0.10$ \\
\hline Glomus fasciculatum & $13.12 \mathrm{~cd} \pm 0.50$ & $49.01 \mathrm{f} \pm 2.20$ & 0.72 cde \pm 0.05 & 2.29 ef \pm 0.05 \\
\hline Fluorescent Pseudomonas + G. fasciculatum & $17.21 \mathrm{~d} \pm 1.27$ & $79.18 \mathrm{~g} \pm 4.51$ & $1.09 \mathrm{e} \pm 0.05$ & $6.26 \mathrm{~g} \pm 1.58$ \\
\hline Fusarium oxysporum & $0.07 \mathrm{a} \pm 0.02$ & $1.51 \mathrm{a} \pm 0.36$ & $0.014 \mathrm{a} \pm 0.004$ & $0.08 \mathrm{a} \pm 0.004$ \\
\hline Rhizoctonia solani & $0.98 \mathrm{ab} \pm 0.09$ & $4.07 \mathrm{ab} \pm 0.30$ & $0.05 \mathrm{a}-\mathrm{d} \pm 0.01$ & $0.238 \mathrm{ab} \pm 0.05$ \\
\hline Fluorescent Pseudomonas + F. oxysporum & $7.46 \mathrm{abc} \pm 1.04$ & 29.11 de \pm 0.65 & 0.67 cde \pm 0.08 & $1.87 \mathrm{de} \pm 0.18$ \\
\hline Fluorescent Pseudomonas $+R$. solani & $5.96 \mathrm{abc} \pm 0.75$ & 20.41 cde \pm 0.48 & $0.52 \mathrm{bcd} \pm 0.15$ & $1.10 \mathrm{bcd} \pm 0.25$ \\
\hline G. fasciculatum + F. oxysporum & $2.08 \mathrm{ab} \pm 0.50$ & $8.08 \mathrm{bcd} \pm 0.65$ & $0.13 \mathrm{ab} \pm 0.03$ & $0.43 \mathrm{ab} \pm 0.05$ \\
\hline G. fasciculatum + R. solani & $2.24 \mathrm{ab} \pm 0.08$ & $5.8 \mathrm{abc} \pm 0.82$ & $0.18 \mathrm{ab} \pm 0.07$ & $0.455 \mathrm{ab} \pm 0.07$ \\
\hline Fluorescent Pseudomonas + G. fasciculatum + F. oxysporum & $8.00 \mathrm{abc} \pm 1.58$ & $41.41 \mathrm{de} \pm 3.01$ & 0.69 cde \pm 0.05 & $1.835 \mathrm{de} \pm 0.13$ \\
\hline Fluorescent Pseudomonas + G. fasciculatum + R. solani & $8.65 b c \pm 0.32$ & $38.60 \mathrm{e} \pm 1.10$ & 0.81 cde \pm 0.08 & $1.49 \mathrm{~cd} \pm 0.66$ \\
\hline F value & 5.98 & 17.14 & 4.73 & 38.82 \\
\hline
\end{tabular}

\pm Standard deviation

$p<0.05$ values marked with different letters in the same column indicates significant differences

\section{REFERENCES}

Akhtar M.S., Siddique Z.A. 2008. Glomus intraradices, Pseudomonas alcaligens, and Bacillus pumilus: effective agents for the control of root - rot disease complex of chick pea (Cicer arietinum L.). J. Gen. Plant Pathol. 74, p. 53.

Bagyaraj D.J., Menge J.A. 1978. Interaction between VA mycorrhizal fungus and Azotobacter and their effects on rhizosphere microflora and plant growth. New Phytol. 80, p. 567.

Barea J.M., Andrade G., Biancioto V., Dowling D., Lohrke S., Bonfante P., O'Gara F., Azcon-Aguilar. 1998. Impact on Arbuscular Mycorrhiza formation of Pseudomonas strains used as inoculants for biocontrol of soil-borne fungal plant pathogens. Appl. Environ. Microbiol. 64, p. 2304.

Bartlett G.R. 1959. Phosphorus assay in column chromatography. J. Biol. Chem. 234, p. 446.

Chanway C.P., Holl F.B. 1991. Biomass increase and associative nitrogen fixation of mycorrhizal Pinus contorta seedlings inoculated with a plant growth promoting Bacillus strain. Can. J. Bot. 69, p. 507.

Duponnois R., Plenchette C.A. 2003. Mycorrhiza helper bacterium enhances ectomycorrhizal and endomycorrhizal symbiosis of Australian Acacia species. Mycorrhiza 13, p. 85.

Egamberdieva D. 2008. Plant growth promoting properties of Rhizobacteria isolated from wheat and pea grown in loamy sand soil. Turk. J. Biol. 32, p. 9.

Gamalero E., Trotta A., Massa N., Copetta A., Martinotti M.G., Berta G. 2004. Impact of two fluorescent pseudomonads and an arbuscular mycorrhizal fungus on tomato plant growth, root architecture and P acquisition. Mycorrhiza 14, p. 185.

Giovannetti M., Mosse B. 1980. An evaluation of techniques for measuring vesicular-arbuscular infections in roots. New Phytol. 84, p. 489.

Khalid A., Arshad M., Zahir Z.A. 2004. Screening plant growth - promoting rhizobacteria for improving growth and yield of wheat. J. Appl. Microbiol. 96: 473-480.
Kloepper J.W., Lifshitz R., Zablotowics R.M. 1989. Free-living bacterial inocula for enhancing crop productivity. Trends Biotechnol. 7, p. 39.

Meyer J.R., Linderman R.G. 1986. Response of substerranean clover to dual inoculation with vesicular-arbuscular mycorrhizal fungi and a plant growth-promoting bacterium, Pseudomonas putida. Soil Biol. Biochem. 18, p. 185.

Phillps J.M, Hayman D.S. 1970. Improved procedures for clearing and staining parasitic and vesicular- arbuscular mycorrhizal fungi for rapid assessment of infection. Trans. Br. Mycol. Soc. 55, p. 158.

Ramamoorthy V., Viswanathan R., Raguchander T., Prakasam V., Samiyappan R. 2001. Induction of systemic resistance by plant growth promoting rhizobacteria in crop plants against pests and diseases. Crop Protect. 20, 1-11.

Umbriet W.W, Burris R.H., Stauffer J.F. 1972. Methods for nitrogen, in Manometric and biochemical techniques. 5th ed. Burgess Publishing Company, Minnesota, 259 pp.

Vazquez M.M, Cesar S.A, Azcon R., Barea J.M. 2000. Interaction between mycorrhizal fungi and other microbial inoculants (Azospirillum, Pseudomonas, Trichoderma) and their effects on microbial population. Appl. Soil Ecol. 15, p. 261.

\section{POLISH SUMMARY}

\section{DZIAŁANIE GLOMUS FASCICULATUM I FLUORYZUJĄCEGO PSEUDOMONAS NA WZROST VIGNA RADIATA (L.) WILCZEK PORAŻONĄ PRZEZ PATOGENY}

Fusarium oxysporum i Rhizoctonia solani są głównymi patogenami przenoszącymi się poprzez glebę, ograniczającymi wzrost i plon roślin. Badano wpływ fluoryzującego Pseudomonas i Glomus fasciculatum na wzrost $V$. radiata w glebie zakażonej patogenami. Procent zasiedlenia przez 
G. fasciculatum powodował wzrost obecności fluoryzującego Pseudomonas i spadek występowania F. oxysporum lub $R$. solani. Jednak indukowana przez patogena redukcja procentu zasiedlenia była ograniczona przez fluoryzujący Pseudomonas. Inokulacja fluoryzującym Pseudomonas lub G. fasciculatum lub obydwoma mikroorganizmami, indukowała znaczny wzrost długości korzeni i pędów, wskaźnika wigoru roślin, zawartości suchej masy i zawartości ogólnego N i P u V. radiata, w porównaniu do kontroli. Wpływ inokulacji był o wiele wyraźniejszy w przypad- ku podwójnej inokulacji roślin, w porównaniu do roślin inokulowanych G. fasciculatum lub fluoryzującym Pseudomonas. Przeciwnie, potraktowanie roślin F. oxysporum lub $R$. solani powodowało spadek długości korzeni i pędów, wskaźnika wigoru roślin, suchej masy i zawartości ogólnego $\mathrm{N}$ oraz $\mathrm{P}$ w testowanej roślinie motylkowej. Jednakże w obecności fluoryzującego Pseudomonas i G. fasciculatum niekorzystne działanie na wzrost patogenów było złagodzone. 